\title{
Identifikasi dan Stratifikasi Massa Air di Laut Sulawesi
}

\author{
Fareza Andre Pahlevi Panjaitan ${ }^{1 *}$, Sri yulina Wulandari ${ }^{1}$, Gentur Handoyo ${ }^{1}$, Gentio Harsono ${ }^{2}$ \\ ${ }^{1}$ Departemen Oseanografi, Fakultas Perikanan dan Ilmu Kelautan, Universitas Diponegoro \\ Jl. Prof. H. Soedarto, S.H, Tembalang Semarang. 50275 Telp/fax (024)7474698 \\ ${ }^{2}$ Pusat Hidro Oseanografi Tentara Nasional Indonesia Angkatan Laut (PUSHIDROSAL), \\ Jalan Pantai Kuta No. V, Jakarta Utara \\ Email: *fareza.app@gmail.com
}

\begin{abstract}
Abstrak
Tujuan dari penelitian identifikasi dan stratifikasi massa air di Laut Sulawesi ini adalah untuk mengidentifikasi tipe massa air dan mengetahui stratifikasi massa airnya. Materi yang digunakan dalam penelitian ini adalah data suhu dan salinitas hingga kedalaman $1500 \mathrm{~m}$ yang didapat dengan menggunakan alat Conductivity Temperature Depth (CTD). Data suhu dan salinitas digunakan untuk mendapatkan tipe massa air dari hasil diagram TS berdasarkan klasifikasi Wyrtki. Adapun untuk penentuan stratifikasi massa air menggunakan kriteria gradien suhu dengan kriteria untuk lapisan termoklin adalah $\geq 0.05^{\circ} \mathrm{C} / \mathrm{m}$. Data suhu dan salinitas divisualisasikan menggunakan software ODV 4.7.3. Hasil pengolahan data menunjukkan bahwa massa air di Laut Sulawesi lebih dipengaruhi oleh massa air dari Samudra Pasifik Utara. Tipe massa air yang ditemukan di laut Sulawesi adalah Western North Pasific Subtropical (WNPS), North Pasific Equatorial Water (NPEW), North Subtropical Lower Water (NSLW) dicirikan dengan salinitas maksimum, North Pacific Intermediate Water (NPIW) dicirikan dengan salinitas minimun, dan South Pacific Intermediate Water (SPIW). Strastifikasi massa air di Laut Sulawesi berdasarkan suhu menunjukkan adanya 3 lapisan massa air yang memiliki kedalaman berbeda - beda di tiap stasiun. Lapisan homogen atau tercampur berkisar pada kedalaman permukaan hingga $85 \mathrm{~m}$, kemudian di bawahnya terdapat lapisan termoklin pada kisaran kedalaman 15 - 263 m, dan di bawah lapisan termoklin terdapat lapisan dalam pada kisaran kedalaman 177 - 1500 m.
\end{abstract}

Kata Kunci: Massa air, Suhu, Salinitas, Stratifikasi Massa Air, Laut Sulawesi

\begin{abstract}
The aims of this research were to identify the type of water masses and to find water masses stratification in Celebes Sea. The materials used in this study were the data of temperature and salinity until $1500 \mathrm{~m}$ depth obtained by using a Conductivity Temperature Depth (CTD). Temperature and salinity data were used to get the type of water masses from the TS diagram based classification Wyrtki. As for the stratification of water masses using the criteria of the temperature gradient with the criteria for the thermocline was $\geq 0.05^{\circ} \mathrm{C} / \mathrm{m}$. Temperature and salinity data were visualized using the ODV software 4.7.3. The results of processing the data showed that the mass of water in the Celebes Sea was influenced by the mass of water from the North Pacific Ocean. Type of water masses found in the Celebes Sea was the Western North Pacific Subtropical (WNPS), North Pacific Equatorial Water (NPEW), North Subtropical Lower Water (NSLW) characterized by salinity maximum, North Pacific Intermediate Water (NPIW) characterized by salinity minimum, and South Pacific Intermediate Water (SPIW). Strastification water masses in the Celebes Sea based on temperature shows three layers of water masses had different depths - depending on each station. Homogeneous or mixed layers at depths ranging from the surface to $85 \mathrm{~m}$, and below it was the depth of the thermocline in the range of 15-263 m, and below the thermocline layer there was a layer within the depth range of $177-1500 \mathrm{~m}$.
\end{abstract}

Keywords: Mass of Water, Temperature, Salinity, Water Mass Stratification, Celebes Sea

\section{PENDAHULUAN}

Secara geografis Indonesia terletak diantara dua benua yaitu Benua Asia dan Benua Autralia, dan terletak diantara dua samudra yaitu Samudra India dan Samudra Pasifik. Hal ini menyebabkan massa air di perairan Indonesia dipengaruhi arus yang sangat spesifik berkaitan dengan dua samudra yang disebut Arus Lintas Indonesia (Arlindo). Salah satu perairan yang menjadi jalur Arlindo adalah Laut Sulawesi. Arlindo dianggap sebagai komponen kunci dalam sistem iklim global (Umasangaji, 2006).

Massa air dari Samudera Pasifik masuk ke Perairan Indonesia melalui dua jalur. Jalur Selat Makassar (jalur barat) mulai dari Selat Mindanao bergerak ke Laut Sulawesi terus bergerak ke Selat 
Makassar, Laut Flores lalu ke Laut Banda. Jalur timur Arlindo masuk melalui Laut Maluku dan Laut Halmahera (Wyrtki, 1961). Ketika melewati perairan Indonesia, maka massa air Arlindo akan bercampur dengan massa air lainnya, sehingga terjadi percampuran massa air dari dua Samudera yang berbeda. Massa air tersebut meliputi suhu, salinitas, oksigen, klorofil, dan tracer lainnya yang dapat dijadikan indikator kesuburan perairan (Setiawan et al., 2013). Laut Sulawesi yang karakteristik massa airnya dipengaruhi Arlindo merupakan daerah laut dalam dengan kedalaman mencapai $4-6 \mathrm{~km}$ yang berpotensi sebagai daerah OTEC dengan memanfaatkan perbedaan suhu permukaan dan laut dalam sebesar $25^{\circ} \mathrm{C}$ (Nontji, 1993).

Tujuan dari penelitian ini adalah untuk menidentifikasi tipe massa air dan stratifikasi massa air di Laut Sulawesi. Massa air yang dimaksud dalam penelitian ini adalah berdasarkan karakteristik fisika seperti suhu dan salinitas, yang mengacu pada pendapat Wyrtki (1961).

\section{MATERI DAN METODE}

Penelitian ini dilaksanakan pada 13 Mei hingga 16 Juni 2016. Adapun lokasi penelitian berada di perairan Laut Sulawesi dengan titik pengambilan data berada diantara $119^{\circ} 00^{\prime}-122^{\circ} 00^{\prime} \mathrm{BT}$ dan $2^{\circ}$ $00^{\prime}-4^{\circ} 00^{\prime}$ LU. Data yang digunakan adalah suhu, salinitas, dan kedalaman yang didapat secara in situ dari alat $C T D$. Penelitian ini menggunakan metode deskriptif kuantitatif untuk menggambarkan kondisi massa air di Laut Sulawesi.

Data suhu, salinitas, dan kedalaman didapatkan dari penurunan CTD Midas 606 Valeport menggunakan KRI Spica 934 milik Dinas Hidro-Oseanografi (Dishidros) TNI-AL. Pada penelitian ini dilakukan pengambilan data pada 12 titik yang mewakili bagian utara, dan selatan Laut Sulawesi. Titik pengambilan data bisa dilihat pada gambar 1 .

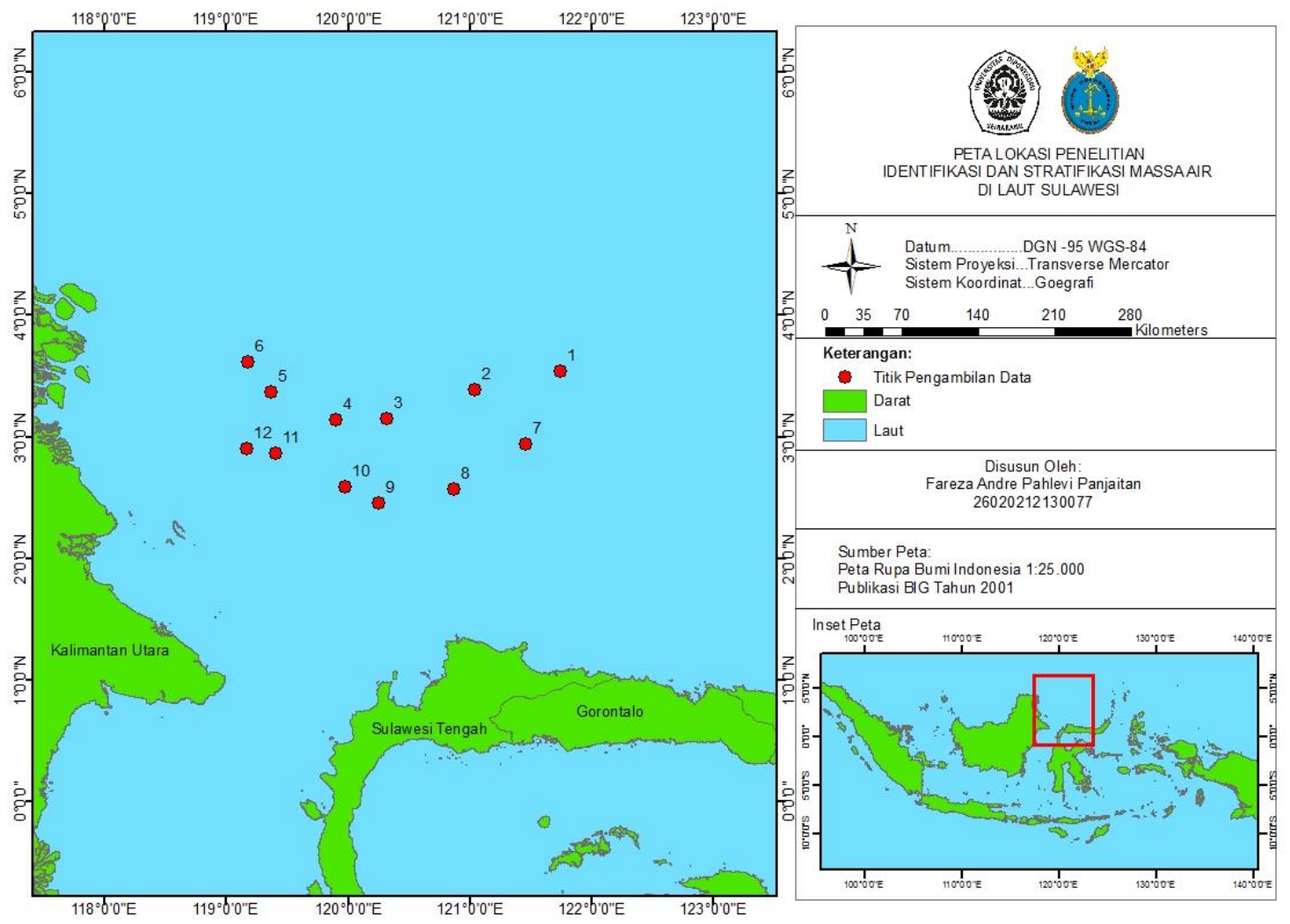

Gambar 1. Peta Lokasi Penelitian

Data suhu, salinitas, dan kedalaman yang didapat dari instrumen CTD selanjutkan dipindahkan ke laptop. Data mentah dengan tipe file vpd kemudian dibuka di Ms. Excel dan dibuat format ASCII. Data ini kemudian disimpan dengan tipe file txt dan diolah dengan ODV 4.7.3. Data suhu dan salinitas 
digunakan untuk menetukan tipe massa air dengan bantuan diagram TS. Sementara untuk menentukan stratifikasi massa air hanya diperlukan perhitungan gradien suhu vertkal pada Ms. Excel sebagai berikut. Gradien suhu vertikal $=-((\mathrm{T} 2-\mathrm{T} 1) /(\mathrm{D} 2-\mathrm{D} 1))$

Keterangan

T : Temperatur

D : Kedalaman

Berdasarkan gradien suhu dapat diketahui bahwa lapisan termoklin adalah lapisan pada kedalaman yang memiliki nilai gradien penurunan temperatur sebesar $\geq 0.05^{\circ} \mathrm{C} / \mathrm{m}$. (Sidabutar et al., 2014). Secara otomatis dapat ditentukan pula lapisan homogen yaitu lapisan berada di atas termoklin, dan juga lapisan dalam yaitu lapisan berada di bawah termoklin.

Data suhu potensial (didapatkan secara in situ) dan salinitas digunakan untuk mengidentifikasi tipe massa air menggunakan diagram T-S (Temperatur-Salinitas) yang mengacu pada Wyrtki (1961) dan Tomczak dan Godfrey (2001). Menurut Purwandana (2012) analisis ini sangat bermanfaat dan mampu memberikan penjelasan terbaik untuk mengenal tipe - tipe air, yakni massa air dengan nilai suhu dan salinitas tertentu dan massa air.

\section{HASIL DAN PEMBAHASAN}

Hasil perhitungan stratifikasi massa air, menunjukkan kedalaman yang relatif bervariasi antar stasiun (Tabel 1).

Tabel 1. Stratifikasi Massa Air Lapisan Termoklin di Laut Sulawesi

\begin{tabular}{|c|c|c|c|c|c|}
\hline Stasiun & $\begin{array}{c}\text { Kedalaman } \\
\text { Termoklin (m) }\end{array}$ & $\begin{array}{c}\text { Batas Atas } \\
\text { (m) }\end{array}$ & $\begin{array}{c}\text { Batas } \\
\text { Bawah } \\
(\mathbf{m})\end{array}$ & $\begin{array}{c}\text { Suhu Batas } \\
\text { Atas }\left(\mathbf{C}^{0}\right)\end{array}$ & $\begin{array}{l}\text { Suhu Batas } \\
\text { Bawah }\left(\mathbf{C}^{0}\right)\end{array}$ \\
\hline 1 & $35-204$ & 35 & 204 & 29,7 & 12,1 \\
\hline 2 & $65-184$ & 65 & 184 & 29,4 & 14,1 \\
\hline 3 & $35-253$ & 35 & 253 & 29,6 & 10,9 \\
\hline 4 & $15-254$ & 15 & 254 & 29,9 & 10,5 \\
\hline 5 & $65-263$ & 65 & 263 & 28,7 & 11,5 \\
\hline 6 & $35-224$ & 35 & 224 & 30,0 & 13,3 \\
\hline 7 & $30-209$ & 30 & 209 & 29,7 & 11,3 \\
\hline 8 & $65-224$ & 65 & 224 & 29,5 & 11,2 \\
\hline 9 & $85-199$ & 85 & 199 & 28,8 & 11,8 \\
\hline 10 & $38-177$ & 38 & 177 & 30,6 & 12,6 \\
\hline 11 & $65-224$ & 65 & 224 & 28,6 & 12,0 \\
\hline 12 & $30-219$ & 30 & 219 & 30,2 & 12,5 \\
\hline \multicolumn{2}{|c|}{ Rata - rata } & 46,9 & 219,5 & 29,5 & 12,0 \\
\hline \multicolumn{2}{|c|}{ Minimum } & 15 & 177 & 28,6 & 10,5 \\
\hline \multicolumn{2}{|c|}{ Maksimum } & 85 & 263 & 30,6 & 14,1 \\
\hline
\end{tabular}

Variasi ini terjadi karena perbedaan batas atas dan batas bawah lapisan termoklin yang berbeda - beda walaupun tidak mencolok. Terlihat bahwa lapisan massa air di laut sulawesi ini terdapat 3 lapisan yaitu lapisan homogen atau tercampur, kemudian lapisan termoklin, dan lapisan dalam. Stratifikasi vertikal ini terjadi karena suhu yang semakin berkurang seiring bertambahnya kedalaman. Yang diakibatkan oleh penyerapan panas dari matahari yang semakin ke dalam semakin berkurang. Lapisan dalam masih dapat teridentifikasi, karena pada penelitian ini kedalaman yang diteliti mencapai $1500 \mathrm{~m}$ dengan suhu rendah mencapai $3.6{ }^{\circ} \mathrm{C}$ yang mencirikan suhu laut dalam. Menurut Nontji (1993), di bawah lapisan termoklin terdapat lagi lapisan yang hampir homogen dan dingin. Semakin ke bawah 
suhunya semakin turun hingga kedalaman lebih dari $1000 \mathrm{~m}$ dan suhu biasanya kurang dari $5{ }^{\circ} \mathrm{C}$. Di bawah 1000 m menuju lantai (dasar) laut, suhu tidak mengalami variasi musiman. Suhu turun perlahan berkisar pada jumlah antara $0{ }^{\circ} \mathrm{C}$ sampai $3{ }^{\circ} \mathrm{C}$. Sesuai dengan pernyataan Supangat dan Susanna (2007), bahwa kisaran suhu tersebut tidak mengalami perubahan di laut dalam baik terhadap geografi (dimanapun tempatnya baik dari kutub hingga ekuator) dan musiman (musim apapun) karena dipengaruhi oleh temperatur dingin dari massa air dengan densitas tinggi yang mengalir dari kutub ke ekuator.

Profil suhu ditunjukkan pada Gambar 2. Terlihat bahwa kedalaman lapisan tercampur (homogen) bervariasi antar stasiun, namun pada lapisan ini suhu relatif seragam dikarenakan efek percampuran dari pengadukan gelombang oleh pengaruh angin. Kuat lemahnya angin ini juga akan mempengaruhi ketebalan lapisan homogen. Lapisan termoklin di Laut Sulawesi teridentifikasi sebagai lapisan termoklin permanen, hal ini dikarenakan letak Laut Sulawesi yang berada di lintang rendah dekat ekuator. Menurut Supangat dan Susana (2007), Termoklin musiman terbentuk pada musim semi dan maksimum (dengan laju perubahan temperatur terbesar terhadap kedalaman atau gradien temperatur paling tajam) pada musim panas. Termoklin tersebut terbentuk di kedalaman beberapa meter dengan lapisan tercampur yang tipis di atasnya. Angin musim dingin yang dingin dan kuat meningkatkan kedalaman termoklin musiman dengan cepat dan menurunkan gradien temperatur. Di lintang rendah (ekuator) tidak terdapat musim dingin sehingga 'termoklin musiman' menjadi 'permanen' dan bergabung dengan termoklin permanen di kedalaman $100-150 \mathrm{~m}$.

Kedalaman lapisan termoklin ini relatif bervariasi namun tidak mencolok. Pada stasiun 4 terdapat kedalaman batas atas termoklin terdangkal yang dimulai dengan kedalaman $15 \mathrm{~m}$. Sementara batas atas termoklin terdalam terdapat pada stasiun 5 yang mencapai kedalaman $85 \mathrm{~m}$. Hal ini berhubungan dengan lapisan homogen di atasnya. Batas atas lapisan termoklin bergantung pada kedalaman lapisan tercampur (yang dipengaruhi oleh proses atmosfer). Diduga efek pengadukan gelombang yang kurang karena kekuatan angin di atasnya yang lemah menyebabkan dangkalnya lapisan homogen dan batas atas termoklin. Hal ini dikarenakan pada musim peralihan (mei), angin umumnya lemah dan pola angin tidak menentu (Nontji, 1993). Menurut Laevastu dan Hela (1970), angin yang kuat akan menyebabkan gelombang yang besar dan dapat menyebabkan pengadukan yang lebih intensif, sehingga lapisan homogen akan semakin dalam. Hal ini selanjutnya menyebabkan bertambahnya kedalaman batas atas lapisan termoklin. Selanjutnya dijelaskan oleh Nontji (1993), bahwa suhu air dipermukaan dipengaruhi oleh kondisi meteorologi. Kondisi meteorologi yang berperan disini antara lain curah hujan, penguapan, kelembaban udara, suhu udara, kecepatan angin, dan intensitas radiasi matahari. Selain itu efek rambatan gelombang Rossby dari Samudra Pasifik ke arah barat diduga juga ikut mempengaruhi, karena terlihat pada isotermal $28-30{ }^{\circ} \mathrm{C}$ yang menunjukan pola yang relatif sama yaitu puncak ke lembah dari stasiun 1 hingga 6 dengan puncak tertingginya berada di stasiun 4 (Gambar 2.c) Sehingga isotermal tersebut terangkat dan batas atas termoklin ikut terangkat. Menurut Schiller et al. (2010) angin zonal sepanjang ekuator Samudra Pasifik dapat berperan sebagai pembangkit gaya permukaan hingga jarak jauh (remote forcing) sehingga menghasilkan gelombang Rossby yang merambat sepanjang ekuator Pasifik dari timur ke barat.

Variasi kedalaman juga terjadi pada batas bawah termoklin. Terjadinya variasi kedalaman batas bawah termoklin diduga dipengaruhi oleh adanya pergerakan massa air dalam yang mempunyai salinitas yang maksimum kemudian di bawahnya mengalir massa air bersalinitas minimum. Sesuai dengan pernyataan Nontji (1993), bahwa massa air yang berada di lapisan termoklin ini berasal dari Samudera Pasifik Utara yang mengalir ke Selat Makassar dan Laut Flores yaitu Massa Air Subtropik Pasifik Utara (Northern Subtropical Lower Water) dengan temperatur massa air $20-24{ }^{\circ} \mathrm{C}$ dan Massa Air Menengah Pasifik Utara (Northern Intermediate Water) dengan temperatur massa air $7-11^{\circ} \mathrm{C}$. 


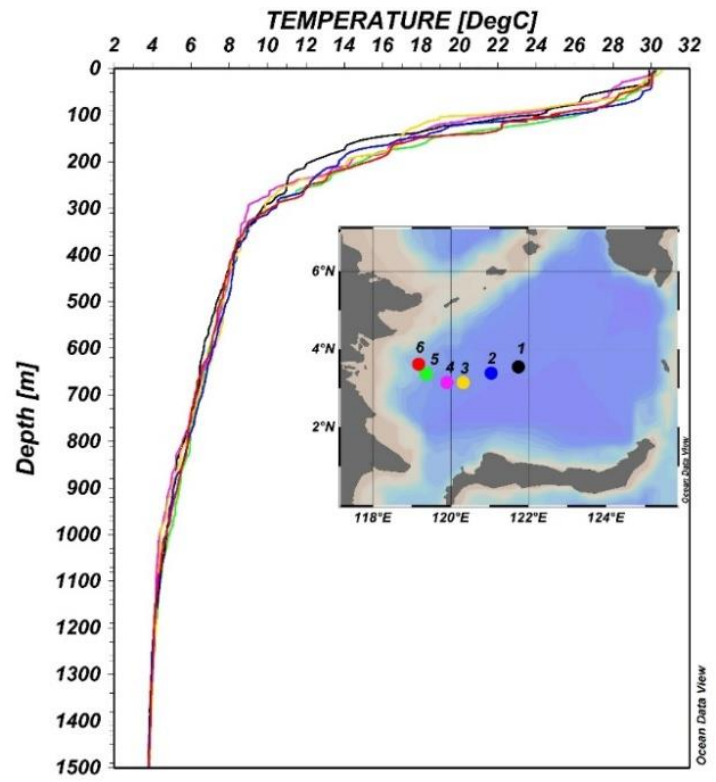

a

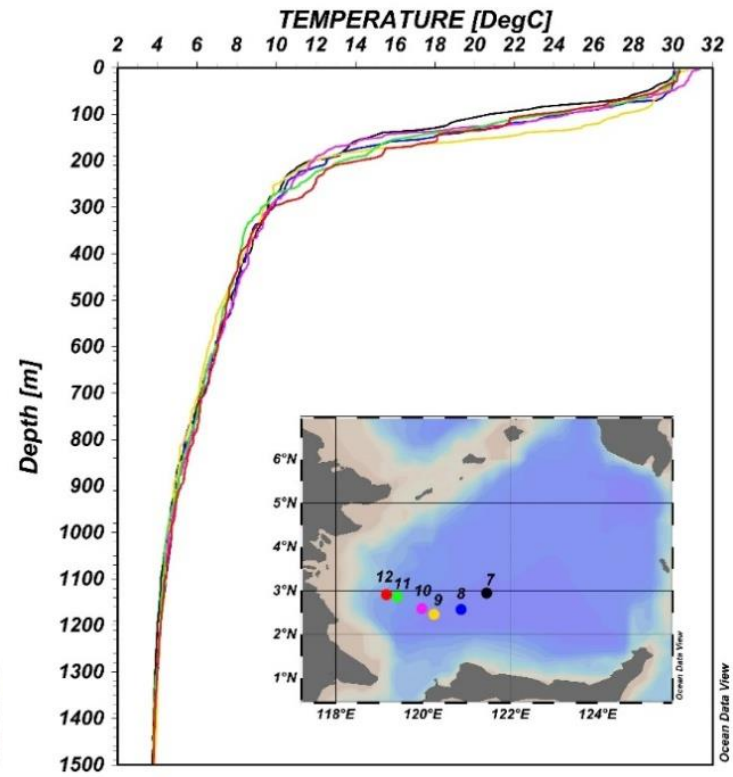

b

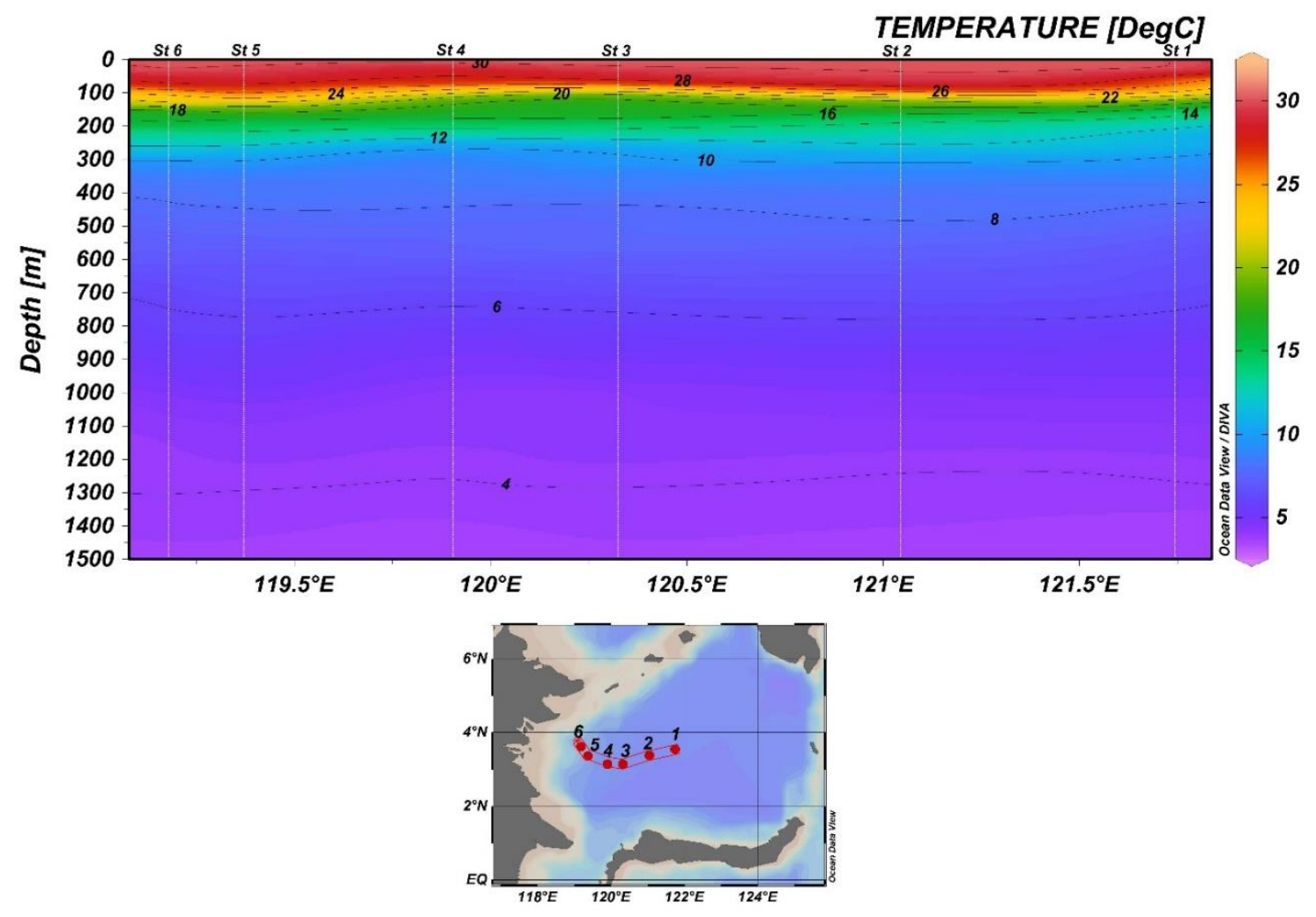

c

Gambar 2. Profil suhu di Laut Sulawesi: a. Transek 1, b. Transek 2, c. Profil horizontal transek 1

Profil salinitas ditampilkan pada Gambar 3. Profil salinitas ini dapat digunakan untuk menelusuri dengan gerakan massa air dengan menggunakan karakteristik sebaran salinitas maksimum dan salinitas minimum dengan menggunakan metode lapisan inti (core layer method). 
Salinitas maksimum di lapisan ini adalah $\geq 34,7$ psu dan mencapai maksimum 35 psu pada kedalaman antara $50-150 \mathrm{~m}$. Kemudian salinitas cenderung menurun tajam hingga 34 psu. Seperti terlihat pada profil melintang salinitas transek 1 , sangat jelas massa air bersalinitas minimum dari stasiun 1 hingga 4 dan pada transek 2 dari stasiun 7 hingga 9. Salinitas minimum ini terdapat di kedalaman 200 - $400 \mathrm{~m}$. Hal ini diduga karena adanya aliran massa air bersalinitas maksimum dan massa air bersalintas minimum dari Samudra Pasifik (Gambar 3.a, 3.b)

Seperti yang dikemukakan oleh Nontji (1993), massa air bersalinitas maksimum tersebut dikenal dengan Air Subtropis Bawah (Subtropical Lower Water), sedangkan massa air bersalinitas minimum tersebut dikenal dengan Air Utara Menengah (Northern Intermediate Water). Massa air ini masuk dari Samudra Pasifik melewati arus Mindanao sampai ke Selat Makassar. Kedua massa air tersebut berasal dari tempat berlainan di Samudra Pasifik. Yang pertama berasal dari air dengan salinitas tinggi yang terjadi di permukaan perairan subtropis di Samudra Pasifik, sedangkan yang kedua berasal dari air kutub utara yang tenggelam dan kemudian menyebar sampai ke khatulistiwa.

Keberadaan massa air salinitas maksimum dan minimum di Laut Sulawesi tersebut dikarenakan adanya Arlindo yang dibawa oleh arus Mindanao Eddy dan arus North Equatorial Current (NEQ) (Tomczak \& Godfrey, 1994). Mengalirnya massa air ini dikarenakan adanya gradien densitas horizotal. Yang mana densitas merupakan fungsi dari suhu dan salinitas. Hal ini sesuai dengan pernyataan Andersson dan Stigebrandt (2004) dalam Zuvela (2006) bahwa transpor Arlindo juga dipengaruhi oleh gradien densitas dan kedalaman perairan.

Perairan yang densitasnya rendah (hangat) mempunyai muka laut yang lebih tinggi daripada perairan yang densitasnya tinggi (dingin), akibatnya terdapat slope (kemiringan) muka laut densitas rendah dengan muka laut densitas tinggi. Karena adanya slope muka laut di lapisan massa air tersebut maka tekanan air di daerah densitas rendah lebih tinggi daripada tekanan air di daerah densitas tinggi. Perbedaan tekanan ini yang membuat massa air mengalir dari tekanan tinggi ke tekanan rendah. Pergerakan massa air ini akan mendapat pengaruh dari gaya coriolis yang akan dibelokkan ke kanan di daerah belahan bumi utara hingga mencapai keseimbangan antara gaya coriolis dengan gaya gradien tekanan Azis (2006) dan Hadi dan Radjawane (2009). Namun karena lokasi dekat ekuator maka pengaruh gaya coriolis akan sedikit.

Di bawah massa air bersalinitas minimum, sebaran salinitas meningkat perlahan semakin bertambahnya kedalaman meskipun peningkatan yang terjadi sangat kecil. Hal ini dikarenakan secara umum air bersalinitas tinggi akan lebih berat dari yang bersalinitas lebih rendah (pada suhu yang sama). Semakin tinggi salinitas, maka akan semakin banyak unsur - unsur penyusun salinitas yang terkandung di dalamnya sehingga bagian yang lebih berat ini akan menempati daerah yang lebih dalam.

Secara membujur terlihat bahwa massa air bersalinitas maksimum stasiun 3 dan 4 pada transek 1 mengalami penipisan (pengurangan nilai salinitas) pada transek 2 di stasiun 9 dan 10 (gambar 3.c). Diduga karena massa air Arlindo di stasiun 3 dan 4 mengalami percampuran saat menuju Selat Makassar melalui stasiun 9 dan 10 dengan semakin berkurangnya identitas salintas maksimum tersebut. Sementara massa air bersalinitas minimum pada stasiun 4 juga tidak terlihat pada stasiun 10 yang mengindikasikan massa air tersebut sudah mengalami percampuran saat menuju Selat Makassar.

Salinitas minimum ini rata - rata hanya terlihat pada stasiun di sebelah timur. Pada transek 1 hanya mencapai stasiun 4 sementara pada transek 2 hanya mencapai stasiun 9. Hal ini dimungkinkan karena massa air salinitas minimum yang berasal dari Samudra Pasifik ini berbelok menuju Selat Makassar setelah melewati stasiun 3 dan 4 pada transek 1 . 


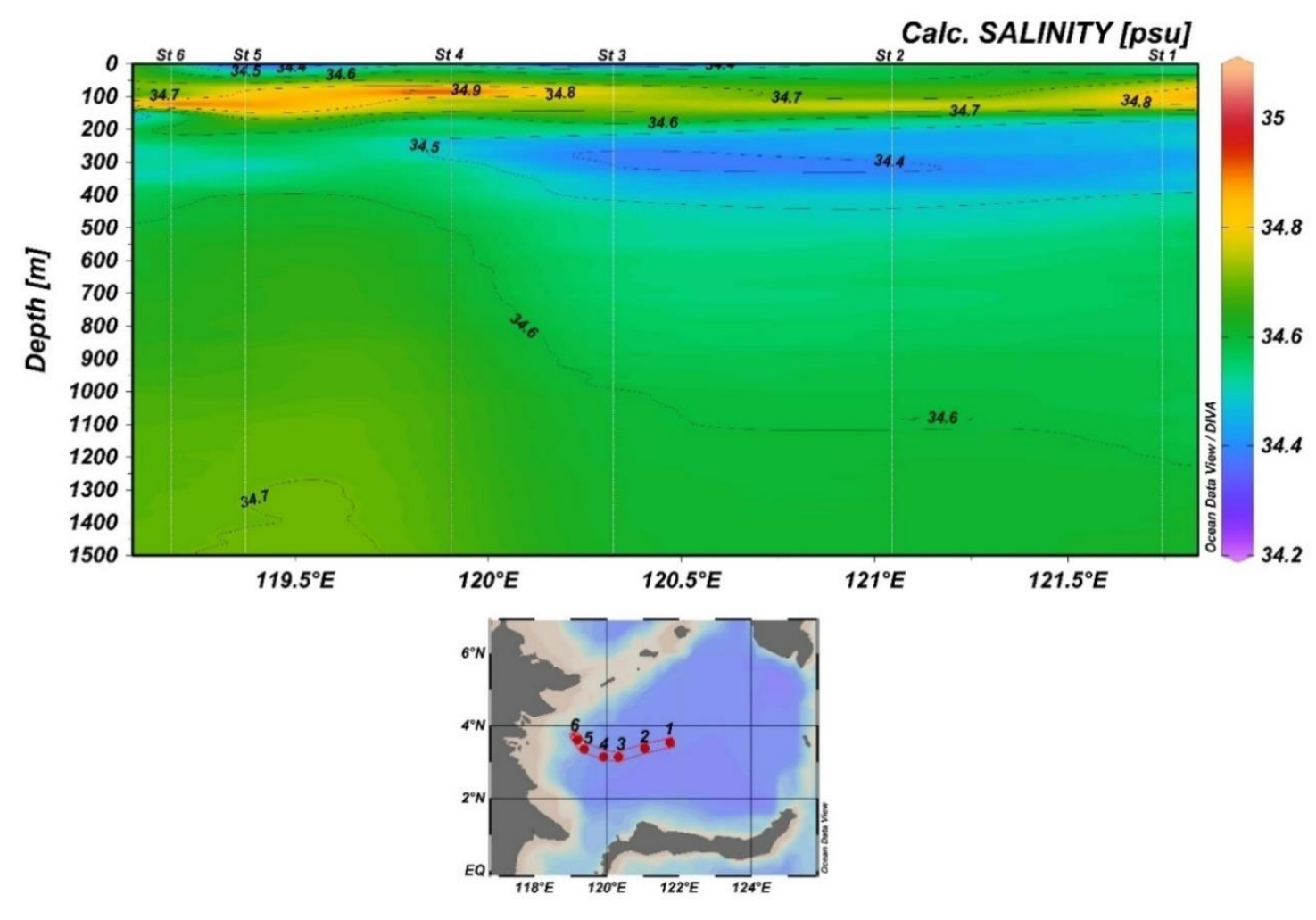

a

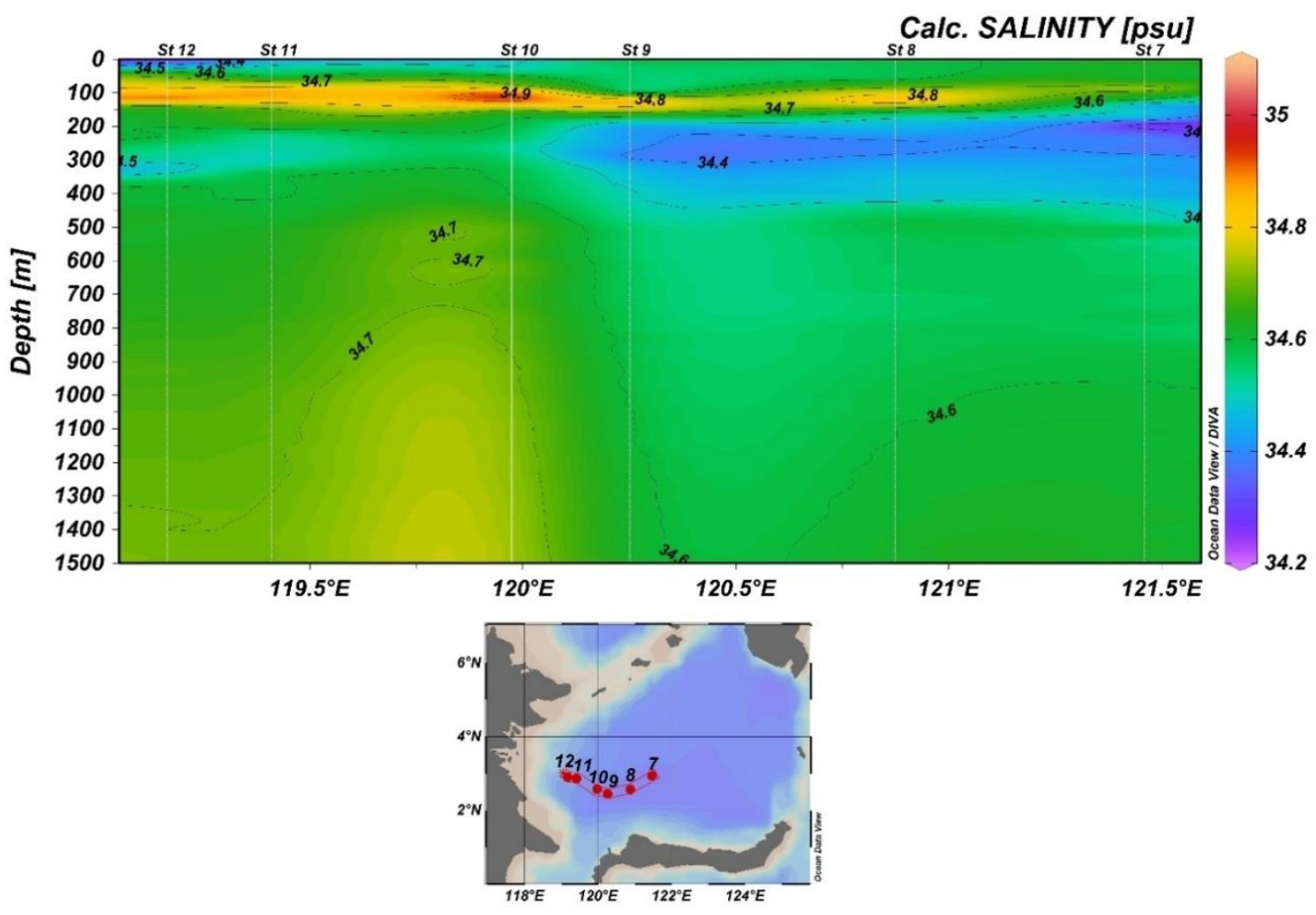

b 

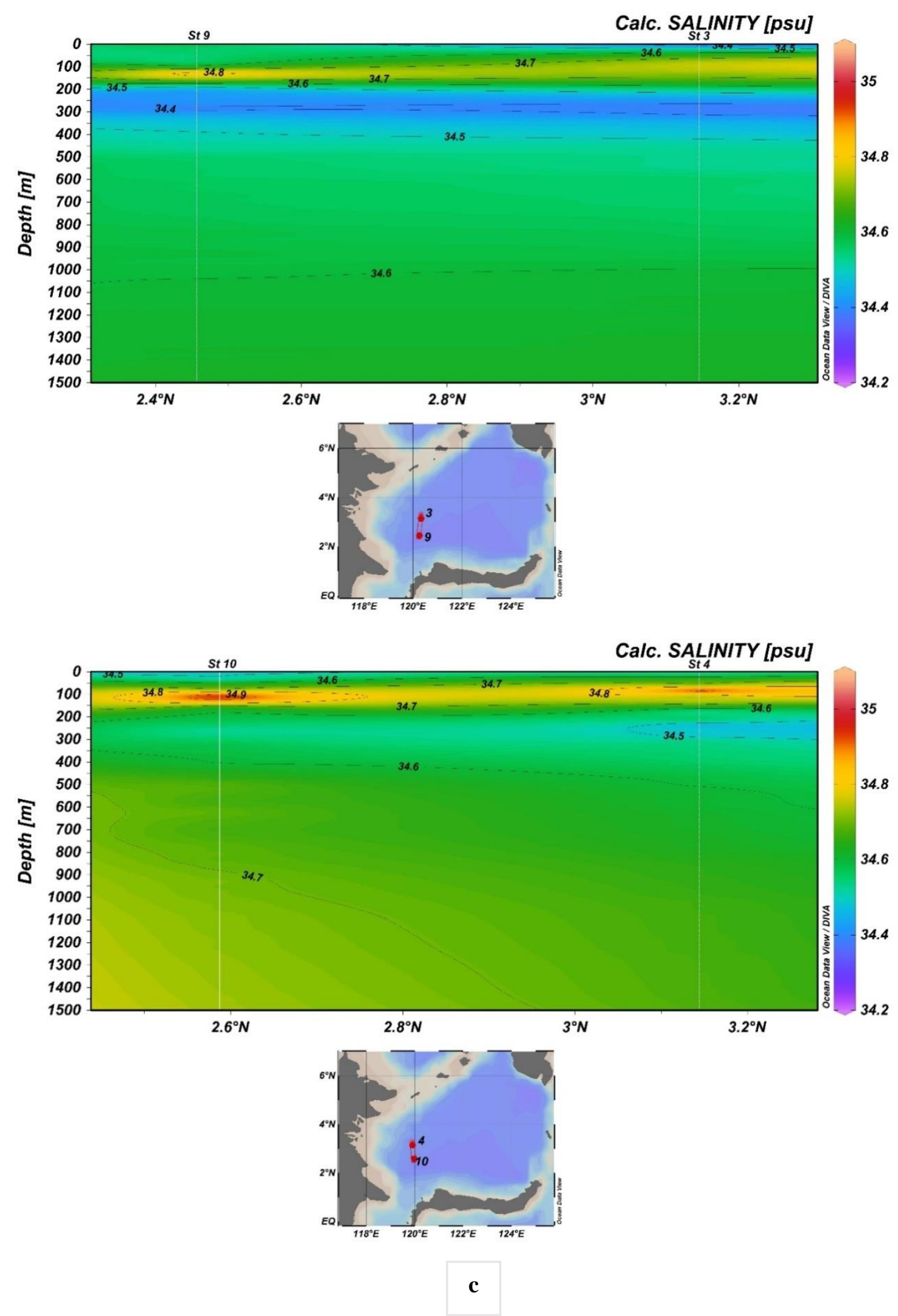

Gambar 3. Profil salinitas: a. Transek 1, b. Transek 2, c. Profil membujur tengah transek 


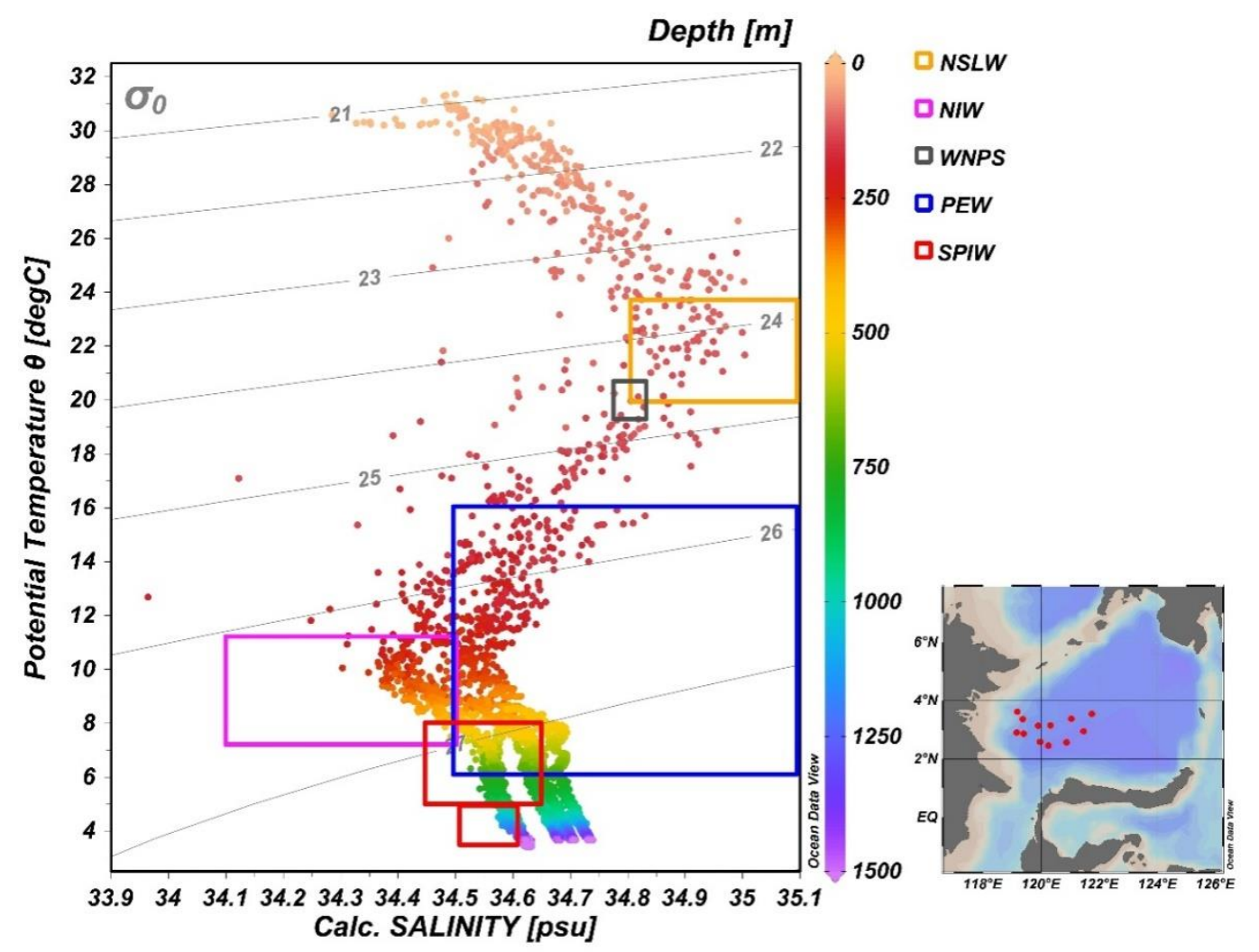

Gambar 4. Diagram T-S (Temperature-Salinity)

Terdapat 5 jenis massa air yang teridentifikasi di Laut Sulawesi (gambar 4) yaitu Western North Pasific Subtropical (WNPS) yang terdapat pada kedalaman $127 \mathrm{~m}$, dicirikan dengan suhu $20^{\circ} \mathrm{C}$ dan salinitas 34.8 psu. Pada kedalaman 142 - 735 m terdapat massa air North Pasific Equatorial Water (NPEW) dengan ciri suhu $6-16^{\circ} \mathrm{C}$ dan salinitas $34.5-35.2$ psu. Kemudian terdapat massa air North Subtropical Lower Water (NSLW) pada kedalaman 94-140 m yang dicirikan oleh nilai temperatur 20 $24^{\circ} \mathrm{C}$ serta salinitas yang berkisar antara 34,8 - 35,2 psu. Massa air ini tersebar merata di semua stasiun. Massa air lainnya yaitu North Pacific Intermediate Water (NPIW) dengan ciri nilai suhu $7-11^{\circ} \mathrm{C}$ dan salinitas 34.1 - 34.5 psu pada kedalaman 213 - 476 m. Berbeda dengan massa air NSLW massa air ini hanya terdapat sampai tengah transek 1 yaitu sampai stasiun 4 yang terlihat sedikit, kemudian sampai stasiun 9 pada transek 2. Massa air ini tidak bergerak hingga bagian barat Laut Sulawesi namun berbelok menuju Selat Makassar.

Keempat massa air ini berasal dari Samudra Pasifik Utara. Kehadirannya terkait dengan adanya sirkulasi massa air Arlindo yang mengalir dari Samudra Pasifik ke Samudra India yang menandakan bahwa massa air di perairan Sulawesi ini dipengaruhi oleh dominasi massa air Pasifik Utara.

Massa air sisanya yaitu North Pacific Intermediate Water (NPIW) dengan ciri suhu $5-8^{\circ} \mathrm{C}$ dan salinitas 34.5 - 34.65 yang terdapat pada kedalaman 417 - $874 \mathrm{~m}$ dan pada kedalaman $874-1378 \mathrm{~m}$ dengan ciri suhu $3.5-5^{\circ} \mathrm{C}$ dan salinitas $34.5-34.6$ psu. Pada stasiun 5, 8, 11, 12 di kedalaman sekitar $417 \mathrm{~m}$ belum dapat dipastikan apakah massa air ini termasuk SPIW atau NPEW karena letaknya yang berada pada wilayah kriteria keduanya dan tidak adanya karkateristik massa air lainnya seperti oksigen yang dapat menguatkan jenis massa massa air yang ada di kedalaman tersebut.

Berbeda dengan penelitian sebelumnya yang dilakukan (Radjawane dan Hadripoetanto, 2014) di perairan Sangihe Talaud (pintu masuk Samudra Pasifik ke Laut Sulawesi) tidak menemukan adanya massa air NPEW sementara untuk hasil dengan menggunakan data survei Arlindo Mixing 1993 tidak menemukan adanya massa air WNPS. 


\section{KESIMPULAN}

Massa air di Laut Sulawesi dipengaruhi oleh massa air dari samudra Pasifik.Tipe massa air yang ditemukan di Laut Sulawesi adalah Western North Pasific Subtropical (WNPS), North Pasific Equatorial Water (NPEW), North Subtropical Lower Water (NSLW) dicirikan dengan salinitas maksimum, North Pacific Intermediate Water (NPIW) dicirikan dengan salinitas minimum, dan South Pacific Intermediate Water (SPIW).

Strastifikasi massa air di Laut Sulawesi berdasarkan suhu menunjukkan adanya tiga lapisan massa air yang memiliki kedalaman berbeda - beda di tiap stasiun. Lapisan homogen atau tercampur berkisar pada kedalaman permukaan hingga $85 \mathrm{~m}$, kemudian di bawahnya terdapat lapisan termoklin pada kisaran kedalaman $15-263 \mathrm{~m}$, dan di bawah lapisan termoklin terdapat lapisan dalam pada kisaran kedalaman $177-1500 \mathrm{~m}$.

\section{UCAPAN TERIMA KASIH}

Ucapan terima kasih disampaikan kepada Pusat Hidro Oseanografi TNI AL (PUSHIDROSAL) atas kesempatan untuk mengikuti Survei dan Pemetaan GENENDRA di Laut Sulawesi.

\section{DAFTAR PUSTAKA}

Azis, M. Furqon, 2006. Gerak Air di Laut. Jurnal Oseana. 31(4): 9 - 21

Hadi, S dan I.M. Radjawane. 2009. Arus Laut. Institut Teknologi Bandung, Bandung, $88 \mathrm{hlm}$.

Wyrtki, K. 1961. Physical Oceanography of the Southeast Asian Waters. Naga Report Volume 2. Scripps Institution of Oceanography, La Jolla, California.

Laevastu, T dan I. Hela. 1970. Fisheries Oceanography. London: Fishing News (Books) LTD.

Nontji, A. 1993. Laut Nusantara. Djambatan, Jakarta, 368 hlm.

Radjawane, I.M. dan P.P. Hadipoetranto. 2014. Karakteristik Massa Air Di Percabangan Arus Lintas Indonesia Perairan Sangihe Talaud Menggunakan Data Index Satal 2010. Jurnal Ilmu dan Teknologi Kelautan Tropis. 6(2): 525-536.

Pond, S. and G.R. Pickard. 1978. Introductory to Dynamic Oceanography. Pergamon Press, Great Britanian.

Purwandana, A. 2012. Transformasi dan Percampuran Massa Air di Perairan Selat Alor pada Bulan Juli 2011. [Tesis]. Sekolah Pascasarsaja, Institut Pertanian Bogor, Bogor.

Schiller, A., S.E. Wijffels., J. Sprintall., R. Molcard., P.R. Oke., 2010. Pathways of intraseasonal variability in the Indonesian Throughflow region. Dynamics of Atmospheres and Oceans. 50:174-200.

Setiawan, A.N., Y. Dhahiyat., N.P. Purba. 2013. Variasi sebaran suhu dan klorofil-a akibat pengaruh Arlindo terhadap distribusi ikan cakalang di Selat Lombok. Depik, 2(2): 58-69.

Sidabutar, H.C., A. Rifai., E. Indrayanti. 2014. Kajian Lapisan Termoklin Di Perairan Utara Jayapura. Jurnal Oseanografi., 3(2): 135-141.

Tomczak M. and J.S. Godfrey. 2001. Regional Oceanography: an Introduction. pdf version 10.1.

Zuvela, M. 2006. Modelling of the Indonesian Througflow on Glacial / Interglacial Time Scales. [Dissertation]. Christian Albrechts Universitä, Macau, 185p. 